\title{
Experimental study of reinforced masonry beams
}

\section{Estudo experimental do comportamento de vigas de alvenaria estrutural armada}

\author{
J. S. CAMACHO \\ jsc@dec.feis.unesp.br \\ https://orcid.org/0000-0001-5145-7703 \\ L. F. CONTADINI a \\ l-contadini@bol.com.br \\ https://orcid.org/0000-0001-5357-898X \\ G. A. PARSEKIAN b \\ parsekian@ufscar.br \\ https://orcid.org/0000-0002-5939-2032
}

\begin{abstract}
An experimental program on reinforced concrete masonry beams was conducted aiming to better understand the behavior of reinforced masonry beams. The beams were designed to fail in flexure, assessing cracking patterns, maximum displacement, ultimate bending moment, and maximum flexural and axial compression strain. The experimental program included 12 reinforced masonry beam tested under flexure and built with bond-beam and hollow concrete blocks. Also, two type of prism were built and tested; one type stacked into the block greater dimension allowing testing with compression in the same direction as in the beams; and the second type as standard grouted prisms. Results indicate an average masonry compression strength parallel to bed joint $25 \%$ lower than the masonry compression strength in the other direction (perpendicular to bed joints). There was a significant increase on the beam stiffness due to the construction of one more block course. The model used to calculate the ultimate bending moment led to values close to the experimental result (difference of about 15\%). Finally, the ultimate average shortening strain of masonry at axial compression was $50 \%$ lower than at flexural compression.
\end{abstract}

Keywords: beam, masonry, reinforced masonry, bending, ultimate strain, compressive strength.

\section{Resumo}

Com objetivo de contribuir com o melhor entendimento do comportamento de vigas de alvenaria estrutural armada, foi realizado o estudo experimental de vigas de alvenaria armada com blocos de concreto. Essas foram projetadas para ruptura à flexão, sendo analisando o modo de fissuração, a flecha, o momento fletor último, a deformação por encurtamento médio último da alvenaria na compressão simples e na flexão. Foi desenvolvido um programa experimental no qual foram ensaiadas, à flexão simples, 12 vigas de alvenaria estrutural armada confeccionadas com canaletas e blocos de concreto. Para comparação entre resistência à compressão da alvenaria paralela e perpendicular às juntas horizontais, foram confeccionados e ensaiados dois tipos de prismas; 4 prismas grauteados, confeccionados com a maior dimensão dos blocos na vertical, simulando a ocorrência das tensões de compressão nas vigas (paralelas às juntas horizontais), e 4 prismas convencionais grauteados. Resultados mostraram que, em média, a resistência à compressão da alvenaria paralela às juntas horizontais foi $25 \%$ menor comparada com a outra direção (perpendicular às juntas horizontais). Houve um aumento significativo da rigidez das vigas devido à inserção de mais uma fiada. $\mathrm{O}$ modelo utilizado para o cálculo do momento fletor último conduziu a valores próximos dos experimentais (diferença de aproximadamente 15\%). E em média, o encurtamento último da alvenaria na compressão simples foi $50 \%$ menor do que na flexão.

Palavras-chave: viga, alvenaria, alvenaria estrutural armada, flexão, deformação na ruptura, resistência à compressão. 


\section{Introduction}

Beams are horizontal elements used to overcome spans over openings. When made in masonry can be constructed with bricks, blocks or with hollow blocks. They are usually reinforced, similarly to concrete beams, allowing expressive increase in flexural strength [1].

Recently, reinforced structural masonry beams were used in the structure of transition floors, called pilotis. However, its use is still limited, perhaps due to lack of knowledge. Thus, knowing more about the behavior of reinforced structural masonry beams, they can be safely more frequently used. Some advantages of the use of reinforced masonry beams are:

Reduction of formwork, since the beam blocks allow building beams from blocks;

- Cost reduction of the carpenter labor to produce structural masonry beams, and;

- Decrease in the final cost of the work if the above items are considered in the costs.

\subsection{Bending behavior and design}

According to [1], [2], [3], [4] and [5], thes following hypotheses are adopted to design reinforced structural masonry:

- In any section, the internal forces are in balance with external forces;

- Strain varies linearly through the depth of the member;

Tension stress in the concrete is equal to zero after cracking;

- Both Steel and masonry have linear elastic behavior for service loads, leading to neutral line passing through the centroid of the cracked section;

- A complete bond exists between the steel and the grout.

Different behavior stages observed, as the loading increases in a reinforced structural masonry beam:
Uncracked Masonry Stage (stage I): the tensile stresses in the maximum tensile section fiber is less than the masonry flexural strength $\left(\mathrm{M}<\mathrm{M}_{\mathrm{cr}}\right)$, with moment-curvature diagram as Figure 1. Before cracking, the stress and deformation distributions along the section are linear, as shown in Figure 2 (a). The section properties can be calculated by the equivalent section, where the steel area is transformed into a masonry area that produces the same deformation, considering the steel and masonry elastic modulus ratio;

- Masonry Cracked-Elastic Stresses Stage (stage II): after exceeding the masonry flexural strength, cracks occur on the tension face and propagates towards the neutral axis until it is possible to restore the section equilibrium. At this stage, in most cases, the compressive at the masonry are small, and the steel still does not yield. As the two materials continue to deform, the curvature increase of the section is linear but with stiffness being continually reduced, as curve $B$ in Figure 1 . The service load moment value, $M_{s}$, shall be in stage. Up to a certain $\mathrm{M}$ limit, the cracked section will continue with elastic behaviour, as illustrated in Figure 2 (b). Ignoring the tensile masonry section area, the force binary (compression and tension forces) are calculated using the section compressed masonry area $(C)$ and " $n$ " times the steel area in the tension area $(T)$. Thus, stresses and strains can be calculated;

- Ultimate-Strength Stage (stage III): close to the failure, masonry stresses are plastic and non-linear, as curve $\mathrm{C}$ of Figure 1. Depending on the reinforcement ratio, steel yielding (With $M$ $=M_{y}$ ) does not occur before the masonry compression-failure. If the section is over reinforced, the masonry will suddenly fail in compression (fragile behavior); if the section is under reinforced, the steel yield strength defines the section maximum moment, and it is possible to calculate the maximum compressive stress in the masonry at this point, balancing the section. Thus, masonry under compression is at a nonlinear behavior

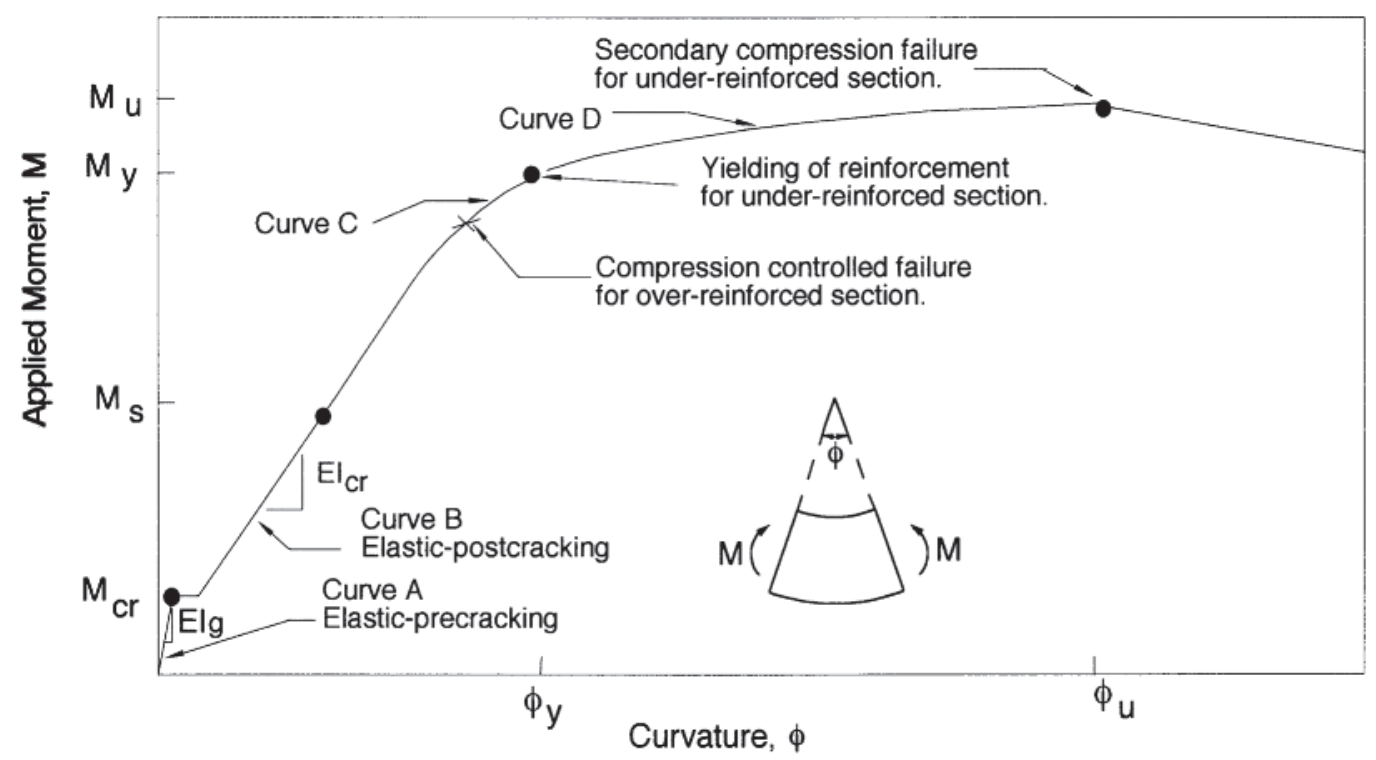

Figure 1

Moment-curvature curve for masonry beams [1] 

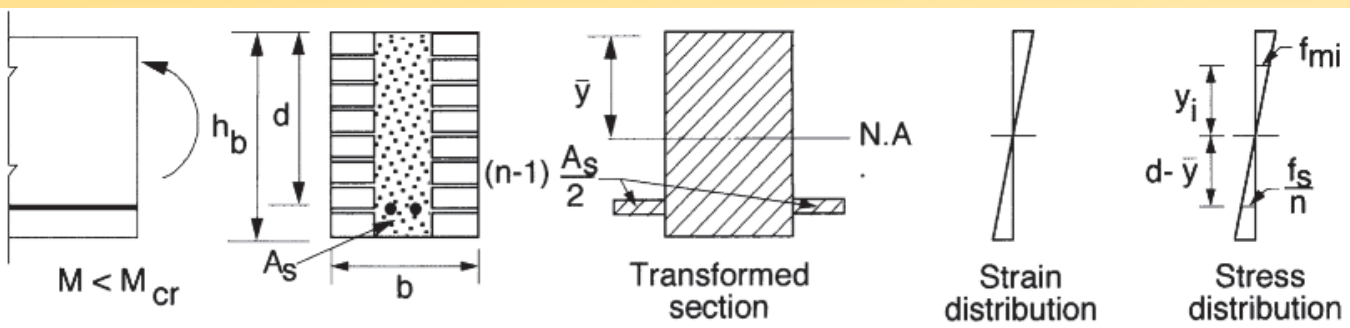

distribution

\section{Stress distribution}
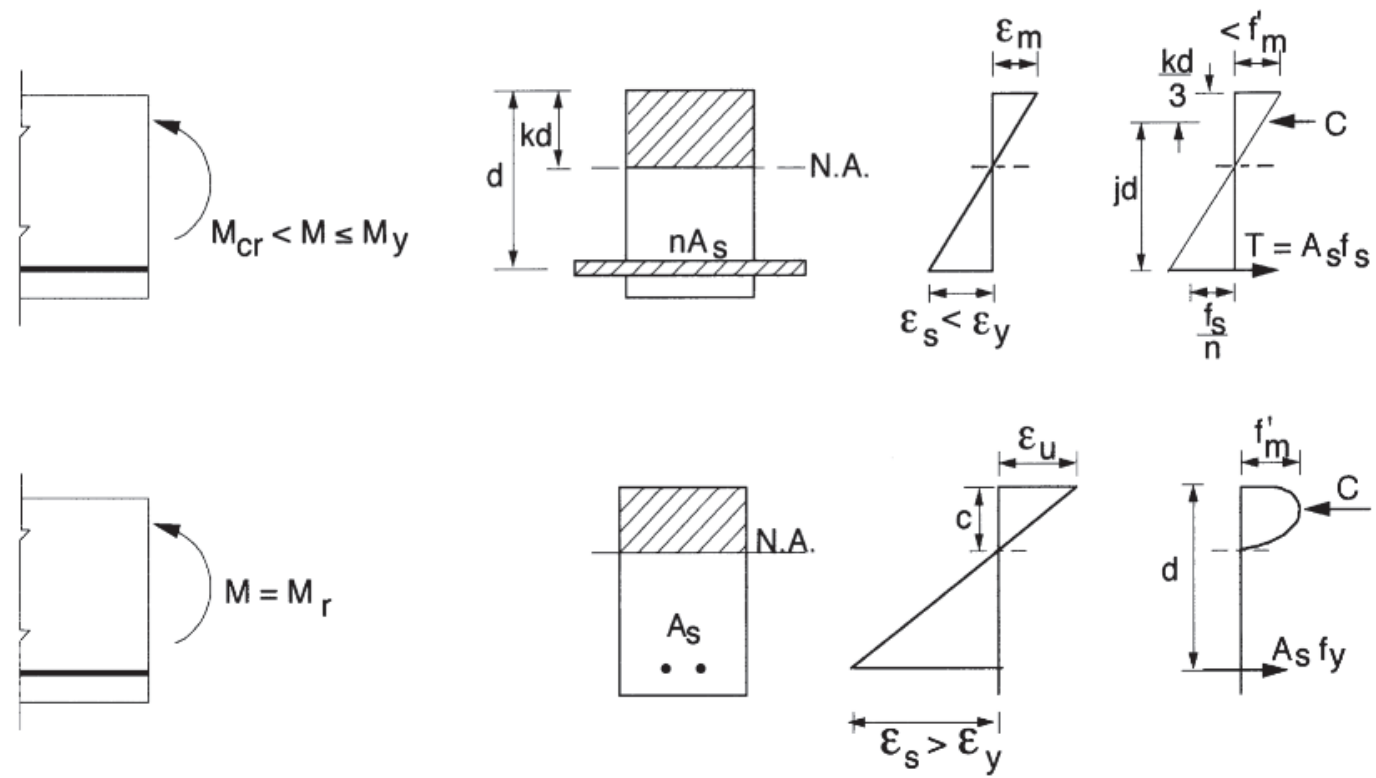

\section{Figure 2}

Reinforced beam analysis of [1]

and the maximum deformation in the upper compressed fiber is limited by the maximum deformation of the masonry $\boldsymbol{\varepsilon}_{u}$, as illustrated in Figure 2 (c). The design requirements must also meet the section ductility condition, guaranteeing the steel yielding. The tensile force will be equal to:

$T=\frac{A_{s} f_{y k}}{\gamma_{s}}$

Where:

$\mathrm{f}_{\mathrm{yk}}=$ steel reinforcement yield strength;

$\gamma_{\mathrm{s}}=$ steel material resistance safety coefficient.
After steel yielding $\left(M>M_{y}\right)$, for every moment increase the section equilibrium is established moving the neutral axis line towards compression face increasing the force-binary lever arm and the compression stress. When the beam is over reinforced, the steel does not reach the yield strength before the masonry compression strength and deformation limit, causing a brittle and sudden failure to occur with small displacements, situation to which the designer should avoid. For this reason, the ductile behavior of under reinforced sections is desirable because of the possibility of load redistribution to less loaded members after the reinforcement yielding and, mainly, the possibility of perceiving beam-failure warnings,

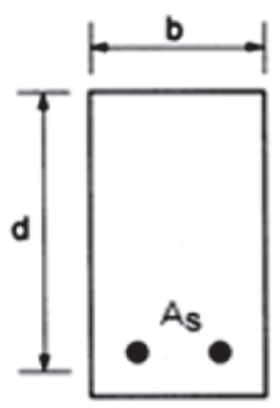

Cross Section

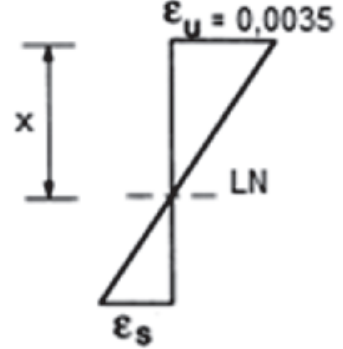

Strain
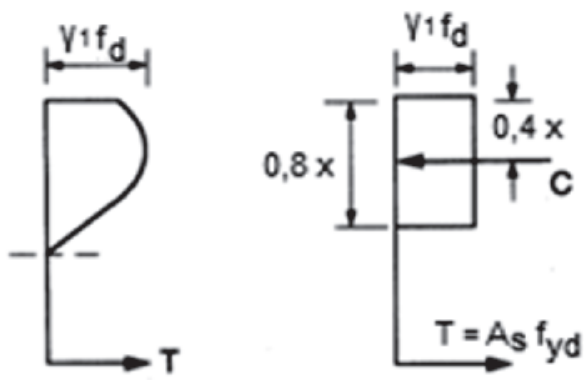

\section{Rectangular Distribuition}

\section{Stresses}

\section{Figure 3}

Section at the ultimate limit state [1] 
characterized by large displacements and crack openings before its rupture. At the limit between the under-reinforced and over-reinforced section, one can calculate the balanced moment, where steel yielding and masonry crushing occurs at the same. This point allow the best use of both materials [1].

The masonry stress-strain diagram is not linear and depends on various factors and properties of the materials. Figure 3 Shows the actual distribution of stresses in the masonry in a flexural section and the approximate rectangular diagram used for dimensioning it, like a reinforced concrete model [6] and [7]. Differences for reinforced concrete include substitution of concrete strength by masonry strength $\left(f_{d}\right)$ and the introduction of the coefficient " $\gamma_{1}$ " which considers the direction of the compression.

\subsection{Codes specifications}

Unlike a wall member, where the compressive stresses act perpendicularly to the horizontal joints, in the reinforced structural masonry beams stresses are parallel to the bed joints, as illustrated in Figure 4.

To estimate the masonry strength and its modulus of elasticity, it is common to test two-block prims loaded perpendicularly to the horizontal joints, due to easy assembly and handling of this specimen type. From the result obtained for the test specimen described above, one can obtain the masonry strength in the other direction (parallel to the horizontal joints) [2], [4] and [9].

Wong and Drysdale (1985) [10] state that the compressive strength of the masonry parallel to the horizontal joints is approximately $25 \%$ less than the compressive strength of the masonry perpendicularly to these joints. The CSA Standard 304.1-04 (2004) [5] recommends that this reduction to be $50 \%$, as well as the NBR 15961-1 (2011) [4], if the compressed region of the element is not

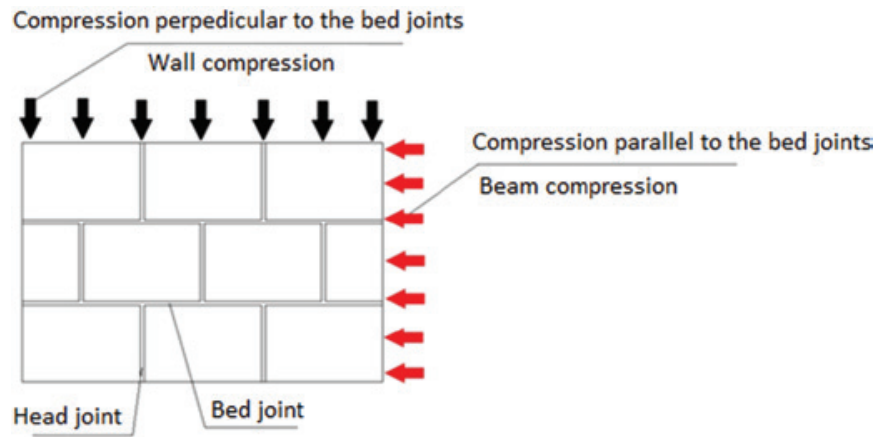

Figure 4

Compression load directions [8]

fully grouted. Ring, Das and Stubbs (2012) [8], when analyzing the resistance of grouted prims (compressive strength of masonry parallel to horizontal joints) and reinforced structural masonry beams (compressive strength of masonry perpendicularly to horizontal joints), stated that the compressive strength of the masonry parallel to the horizontal joints was approximately $53 \%$ higher, compared to the compressive strength of the masonry in the other direction. Table 1 shows the equations specified by international coded AS 3700-2001 (2001) [2], BS 5628-2 (2005) [3] and NBR 15961-1 (2011) [4] to design reinforced structural masonry beams and Table 2 shows the material and load coefficients adopted by each code. In NBR 15961-1 (2011) [4], in addition to using the coefficient of reduction of the steel strenght $\left(\gamma_{s}\right)$, the standard reduces the steel yield strength by $50 \%$. In a simplistic way, this specification can be understood as an extra safety factor to the flexural design. According to Parsekian et. Al (2012) [1], this reduction not present in international codes as 3700-2001 (2001) [2], BS 5628-2 (2005) [3] and

\section{Table 1}

Expressions for the lever arm ( $\mathrm{z})$ and design bending moment $\left(\mathrm{M}_{\mathrm{d}}\right)$ for reinforced structural masonry beams design from the codes AS 3700-2001 (2001) [2], BS 5628-2 (2005) [3] and NBR 15961-1 (2011) [4]

\begin{tabular}{ccc}
\hline Code & Lever arm & Design bending moment (M $)$ \\
\hline $\begin{array}{c}\text { AS 3700-2001 } \\
(2001)\end{array}$ & $d \cdot\left[1-\frac{0,60 \cdot A_{s d} \cdot f_{s y}}{\left(1,3 \cdot f_{m}^{\prime}\right) \cdot b \cdot d}\right]$ & $\left.\phi \cdot f_{s y} \cdot A_{s d} \cdot d \cdot\left[1-\frac{0,6 \cdot f_{s y} \cdot A}{\left(1,3 \cdot f_{s d}^{\prime}\right.}\right] \cdot b \cdot d\right]$ \\
\hline $\begin{array}{c}\text { BS 5628-2 } \\
(2005)\end{array}$ & $d \cdot\left(1-\frac{0,50 \cdot A_{s} \cdot f_{y} \cdot \gamma_{m m}}{b \cdot d \cdot f_{k} \cdot \gamma_{m s}}\right) \leq 0,95 \cdot d$ & $\frac{A_{s} \cdot f_{y}}{\gamma_{m s}} \cdot d \cdot\left(1-\frac{0,5 \cdot A_{s} \cdot f_{y} \cdot \gamma_{m m}}{b \cdot d \cdot f_{k} \cdot \gamma_{m s}}\right) \leq \frac{0,4 \cdot f_{k} \cdot b \cdot d^{2}}{\gamma_{m m}}$ \\
\hline $\begin{array}{c}\text { NBR 15961-1 } \\
(2011)\end{array}$ & $d \cdot\left(1-\frac{0,50 \cdot A_{s} \cdot f_{s}}{b \cdot d \cdot f_{d}}\right) \leq 0,95 \cdot d$ & $A_{s} \cdot f_{s} \cdot d \cdot\left(1-\frac{0,5 \cdot A_{s} \cdot f_{s}}{b \cdot d \cdot f_{d}}\right) \leq 0,4 \cdot f_{d} \cdot b \cdot d^{2}$ \\
\hline
\end{tabular}

Note: According to NBR 15961-1 (2011): $f_{d}=\frac{f_{k}}{\gamma_{m}}$ and $f_{s}=0,5 . \frac{f_{y k}}{\gamma_{s}}$

\section{Table 2}

Values of the material reduction or safety coefficients from the codes AS 3700-2001 (2001) [2], BS 5628-2 (2005) [3] and NBR 15961-1 (2011) [4]

\begin{tabular}{ccccc}
\hline AS 3700-2001 (2001) & BS 5628-2 (2005) & NBR 15961-1 (2011) \\
\hline$\phi$ & $\gamma_{\mathrm{mm}}$ & $\gamma_{\mathrm{ms}}$ & $\gamma_{\mathrm{m}}$ & $\gamma_{\mathrm{s}}$ \\
0.75 & 2.3 & 1.5 & 2.0 & 1.5 \\
\hline
\end{tabular}




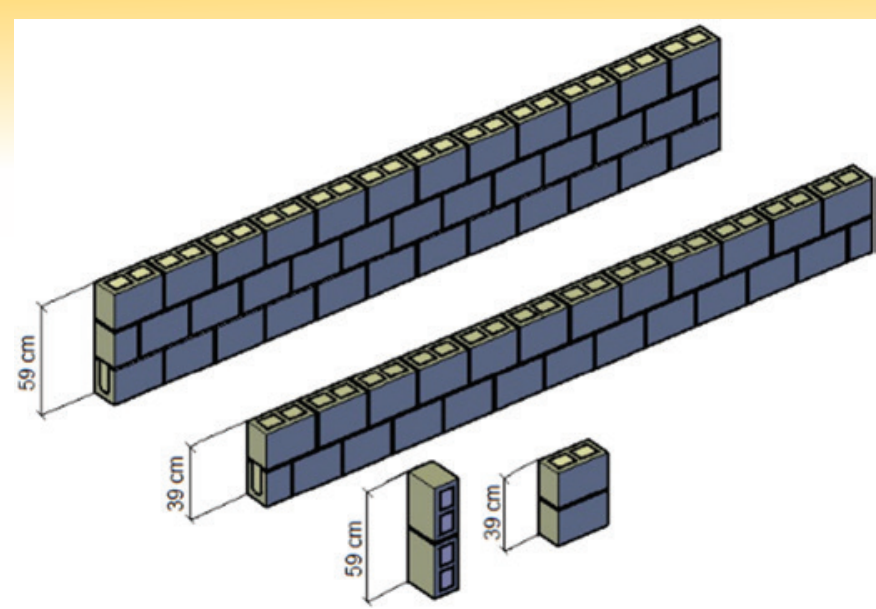

Figure 5

Specimens tested

CSA S304.1-04 (2004) [5]. It is considered in the Brazilian code due to the limited number of researches on structural masonry beams and because of questioning on the perfect adhesion condition between the grout and masonry interfaces.

In relation to the maximum masonry strain at ultimate moment, the standards AS 3700-2001 (2001) [2], BS 5628-2 (2005) [3] and NBR 15961-1 (2011) [4] specify its value as $3.5 \%$, while CSA S 304.1-04 (2004) [5] adopts the value of 3.0\%o. In the work carried out by Suter And Fenton (1986) [7], the authors obtained the average masonry flexural compression as $3.4 \%$.
On the cracking pattern of reinforced structural masonry beams, when analyzing the contribution of the transverse reinforcement to the shear strength, Fereig [11] concluded that the cracks are spread along the horizontal and vertical joints, also observed by Landini (2001) [12] and Ramos (2012) [13].

\section{Materials and experimental program}

Twelve reinforced structural masonry were tested to pure bending, with varying heights - beams of 2 and 3 courses - and longitudinal reinforcement. The first course was always built with beam-blocks and the other courses with hollow blocks. Seven beams had the transversal section of $(14 \times 39) \mathrm{cm}$ and five beams had the transversal cross section of $(14 \times 59) \mathrm{cm}$.

Four special prims specimens with the grouted blocks laid by the largest lateral face, here called "lateral prism", and four conventional grouted prims were also tested. Each type of prism was twoblock high. The lateral prims had a total height of $59 \mathrm{~cm}$ and the conventional prims were $39-\mathrm{cm}$ high. Figure 5 shows the types of beams and prims specimens at the research program.

Beam-blocks and regular hollow-blocks (concrete blocks) of dimensions $(14 \times 19 \times 29) \mathrm{cm}$ and $(14 \times 19 \times 14) \mathrm{cm}$ were used to manufacture the structural masonry beams. The lateral prisms and the regular prisms were assembled using regular hollow-concrete blocks $(14 \times 19 \times 29) \mathrm{cm}$. According to NBR 6136 (2014) [14], the concrete blocks were classified as class $A$.

Grout, mortar, block and prism specimens, illustrated in table 3 , were tested to axial compression, after 28 days of the specimens molding, obtaining the compression strength of each.

\section{Table 3}

Grout and mortar mix proportions

\begin{tabular}{cc}
\hline Grout & Mortar \\
\hline Cement: Lime: Fine Aggregate: Coarse Aggregate & Cement: Lime: Fine Aggregate \\
Mix proportion by volume: $1: 0.10: 1.50: 1.60$ & Mix Proportion by Volume: $1: 2.50: 4.50$ \\
Mix proportion by mass: $1: 0.05: 2.40: 2.30$ & Mix Proportion by Mass: $1: 1.34: 7.19$ \\
Water/Cement ratio $=0.65$ & Water/Cement Ratio $=1.70$ \\
\hline
\end{tabular}
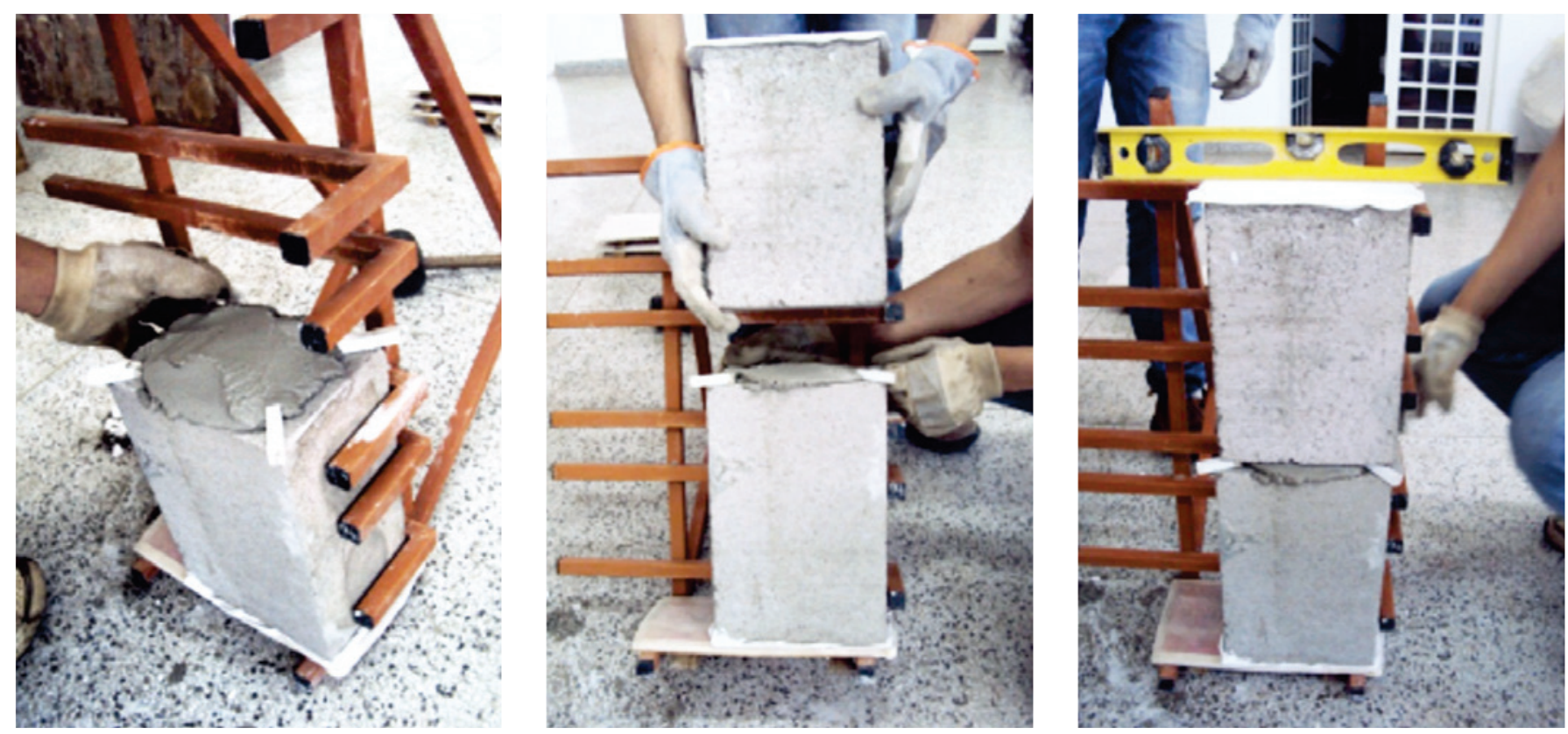

Figure 6

Prism construction 
Table 4

Data of the reinforced structural masonry beams

\begin{tabular}{|c|c|c|c|c|}
\hline Beam specimen & $\begin{array}{c}b \\
(\mathrm{~cm})\end{array}$ & $\begin{array}{c}\mathrm{h} \\
(\mathrm{cm})\end{array}$ & $\begin{array}{c}d \\
(\mathrm{~cm})\end{array}$ & $\begin{array}{c}\text { As } \\
\left(\mathrm{cm}^{2}\right)\end{array}$ \\
\hline $\mathrm{V} 2 \mathrm{~F} 1$ & \multirow{12}{*}{14} & \multirow{7}{*}{39} & 29.20 & \multirow{2}{*}{$\phi 10.0 \mathrm{~mm}=0.80 \mathrm{~cm}$} \\
\hline $\mathrm{V} 2 \mathrm{~F} 2$ & & & 31.00 & \\
\hline $\mathrm{V} 2 \mathrm{~F} 3$ & & & 31.00 & \multirow{2}{*}{$\phi 20.0 \mathrm{~mm}=3.15 \mathrm{~cm}$} \\
\hline V2F4 & & & 30.50 & \\
\hline V2F5 & & & 30.80 & \multirow{4}{*}{$\phi 25.0 \mathrm{~mm}=5.00 \mathrm{~cm}$} \\
\hline V2F6 & & & 31.20 & \\
\hline V2F7 & & & 31.00 & \\
\hline V3F1 & & \multirow{5}{*}{59} & 53.00 & \\
\hline V3F2 & & & 52.40 & \\
\hline V3F3 & & & 51.60 & \multirow{3}{*}{$\phi 32.0 \mathrm{~mm}=8.00 \mathrm{~cm}$} \\
\hline V3F4 & & & 51.60 & \\
\hline V3F5 & & & 52.80 & \\
\hline
\end{tabular}

\subsection{Specimens naming}

When showing the results, the reinforced structural masonry beams will are described using 4 characters: The first is the letter $\mathrm{V}$, abbreviation of beam ("Viga" in Portuguese), the second character if number 2 or 3 pursued depending on the number of coursed of beam ( 2 or 3 courses), the third character of the letter F (meaning "Fiada" as course in Portuguese), and the fourth character is the beam specimen numbering, from 1 to 7 for the 2-course (2F) beams, and from 1 to 5 for the 3 -course (3F) beams.

\subsection{Prism construction}

The blocks used to build the lateral prims were positioned and wet before grouting, and after consolidated with an immersion vibrator. In the curing process, the grouted blocks were covered with a plastic film at the top for 5 days and, within this period, frequently wetted. After the curing period, they had one of the surfaces regularized with gypsum capping, the other was left without the regularization to receive the bedding mortar. The assembling sequence is illustrated in Figure 6 .

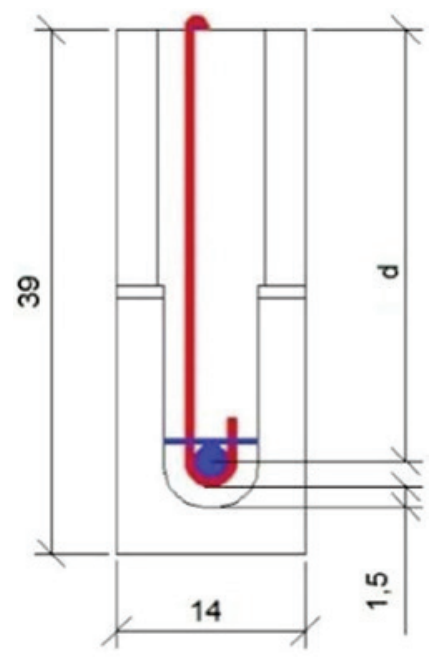

a 2-course beams

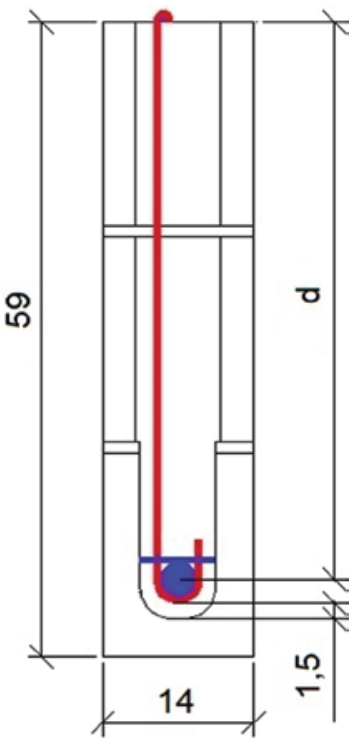

b 3-course beams

\section{Figure 7}

Cross section of the 2 and 3 course beams dimensions in centimeter

\subsection{Reinforced structural masonry beams construction}

Firstly, the beam-block first course was assembled, uniting them with by the head joint bedding mortar throughout the beam-block transversal area. After 2 days of mortar curing, the reinforcement steel bars were mounted inside the beam-block channel. The structural masonry beams were reinforced with one positive longitudinal bar, with one negative longitudinal bar (stirrup-hold bar) and with one-leg stirrups along its length. The stirrups had end-hooks involving the top and bottom longitudinal reinforcement. Figure 7 (a) and 7 (b) detail the transversal cross section of each beam type.

In all beams, the stirrup diameter was $6.3 \mathrm{~mm}$ and the transverse reinforcement area equal to $4.4 \mathrm{~cm} 2 / \mathrm{m}$, which was dimensioned to avoid shear failure. Table 4 summarizes the reinforced structural masonry beams data.

With the positioning of the frame within the channel, the remaining courses were full-bedded laid with mortar. Grouting occurred after 2 days of mortar curing, when the beams were wet to reduce grout shrinkage problems, and the grout was consolidated with an immersion vibrator. The curing process consisted of covering the region of the exposed grout with a plastic film for 7 days and, during this period, they were frequently wetted.

To facilitate cracks visualization during the test, the beams were painted

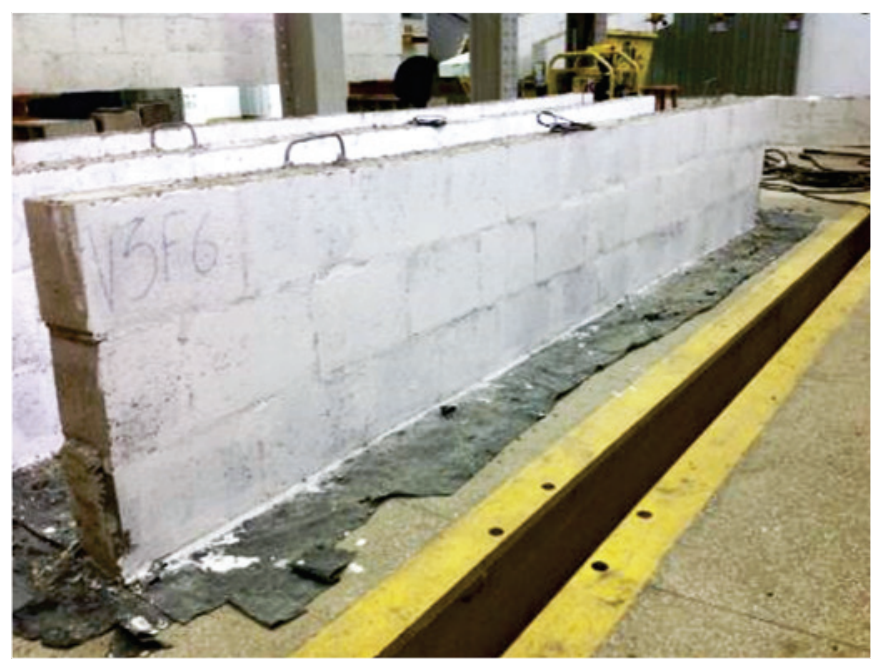

Figure 8

Structural masonry beam to be tested 


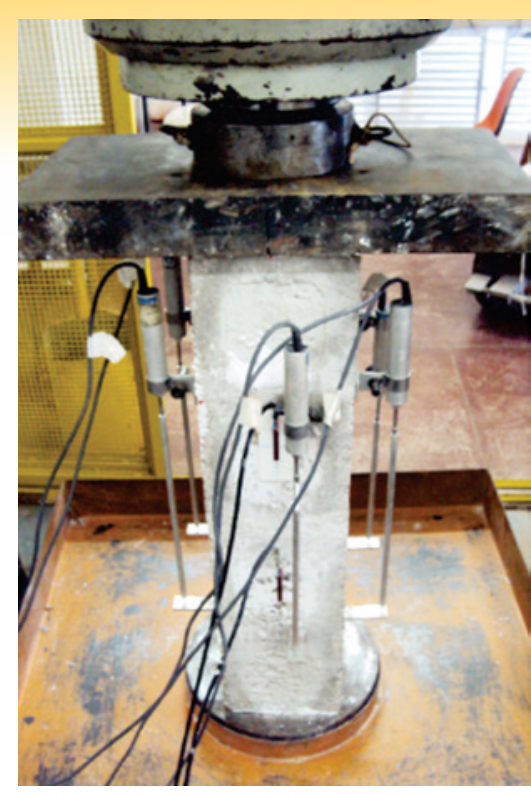

a Prism testing
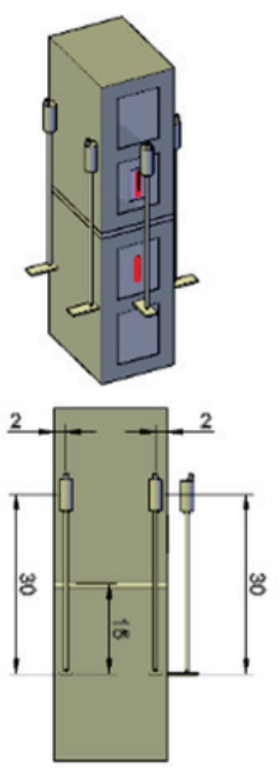
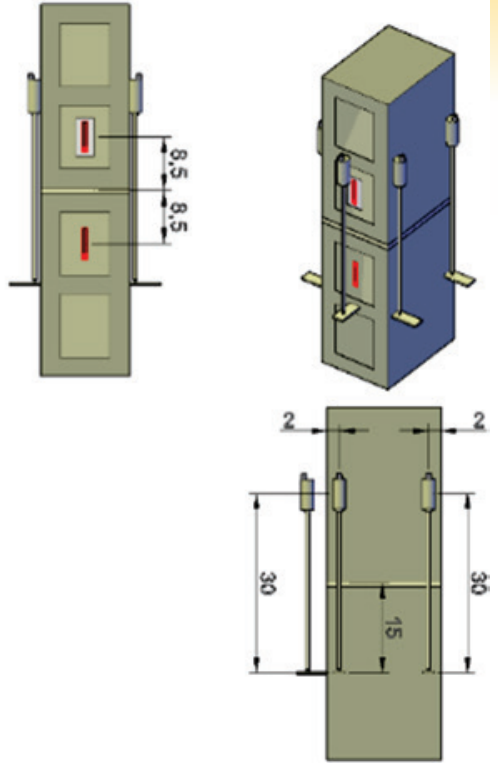

b Instrumentation- dimensions in centimeters

\section{Figure 9}

Lateral prism testing and instrumentation

with acrylic-resin-based paint (water-based acrylic paint) dissolved in water, into two coats so that it would not form a thick layer of the painting. The final result of the beams assemblage is shown in Figure 8.

\subsection{Test instrumentation}

In the prism's simple compression testing, a hydraulic testing machine with a maximum capacity of $1,000 \mathrm{kN}$ with spherical seat compression plates for loading application was used. In each prism, the shortening of the masonry in the axial compression was obtained by

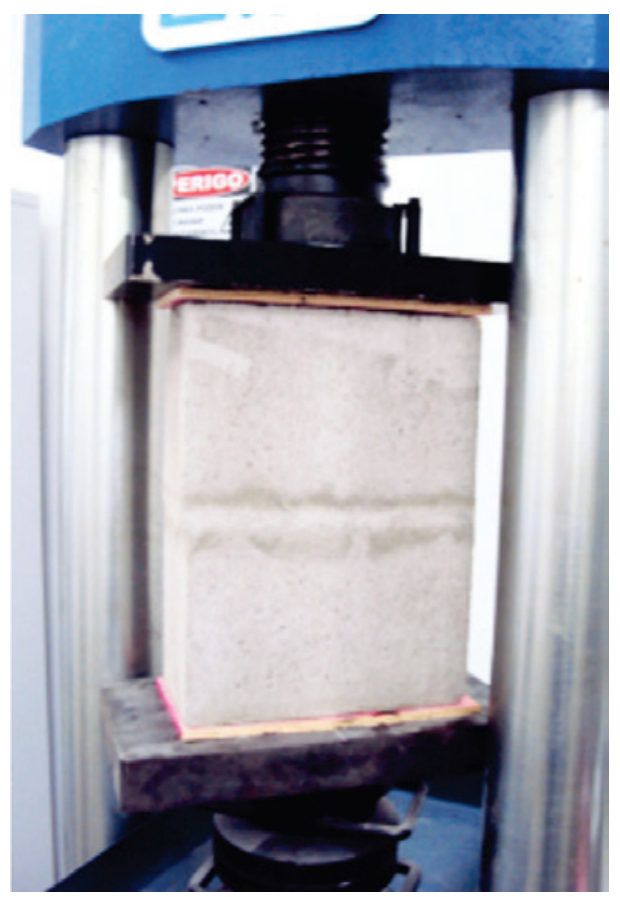

Figure 10

Regular prism testing the mean of the deformation of the 5 LVDTs fixed along the specimens, 4 on the sides and 1 in the front face. For the regular prims testing, a hydraulic machine with a maximum capacity of 2,000 kN was used to obtain the compression strength. Figures 9 (a), 9 (b) and 10 show the test instrumentation scheme using during the lateral prism testing and during the regular prism testing, respectively. For pure bending testing of the beams, a simple supported span of 300 $\mathrm{cm}$ was designed to the $359-\mathrm{cm}$ long beams, into four-point loading. In the case of the 2-course beams, wood beams were used to spread the load to each loading point. For the 3-course beam testing steel I-section were used to spread the load. Each load point was at a $30-\mathrm{cm}$ distance center of the span, obtaining a $60-\mathrm{cm}$ long region with pure bending moment, as illustrated in Figures 11 (a) and 11 (b). In each beam, one displacement transducer was placed at the mid-span at the top face of the beam to the masonry flexural shortening strain. One strain-gage was glued to the positive reinforcement bar, also at mid-span. Also, two displacement gages were placed on each of the beam face.

\section{Results and discussions}

\subsection{Average compressive strength of blocks, mortar and grout}

Table 5 summarize the average compressive strength of the mortar, grout and blocks used.

\section{Table 5}

Average compressive strength

\begin{tabular}{ccc}
\hline Material & $\begin{array}{c}\text { Average } \\
\text { compressive } \\
\text { strength } \\
(\mathrm{MPa})\end{array}$ & $\begin{array}{c}\text { Coefficient } \\
\text { of variation } \\
(\%)\end{array}$ \\
\hline Concrete block* & 12.64 & 15.07 \\
Grout & 23.23 & 4.63 \\
Mortar $-(5 \times 10) \mathrm{cm}$ & 6.68 & 4.88 \\
Mortar $-(4 \times 4 \times 4) \mathrm{cm}$ & 8.46 & 2.63 \\
\hline
\end{tabular}




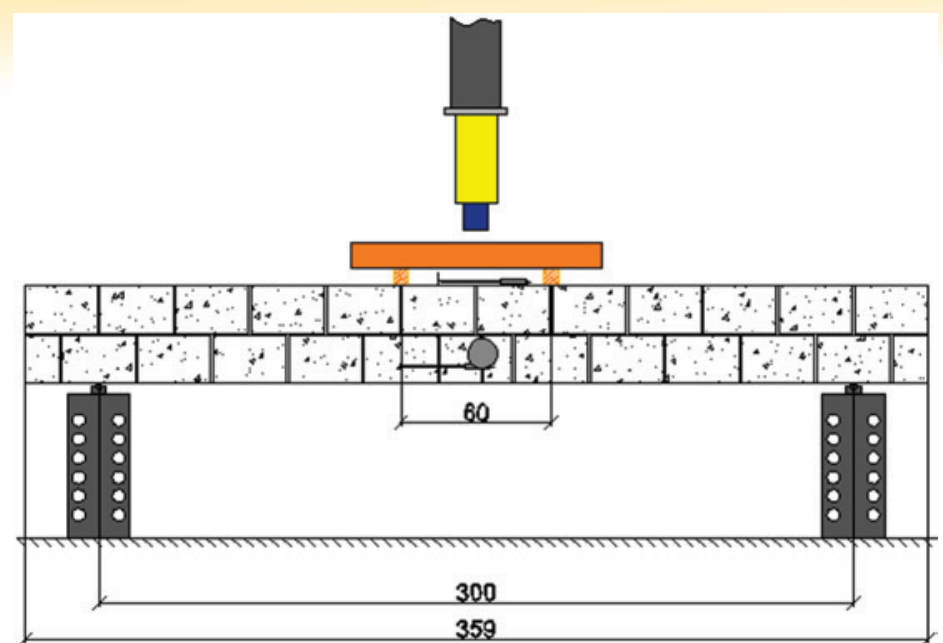

a Test set-up for the 2-course beams dimensions in centimeter

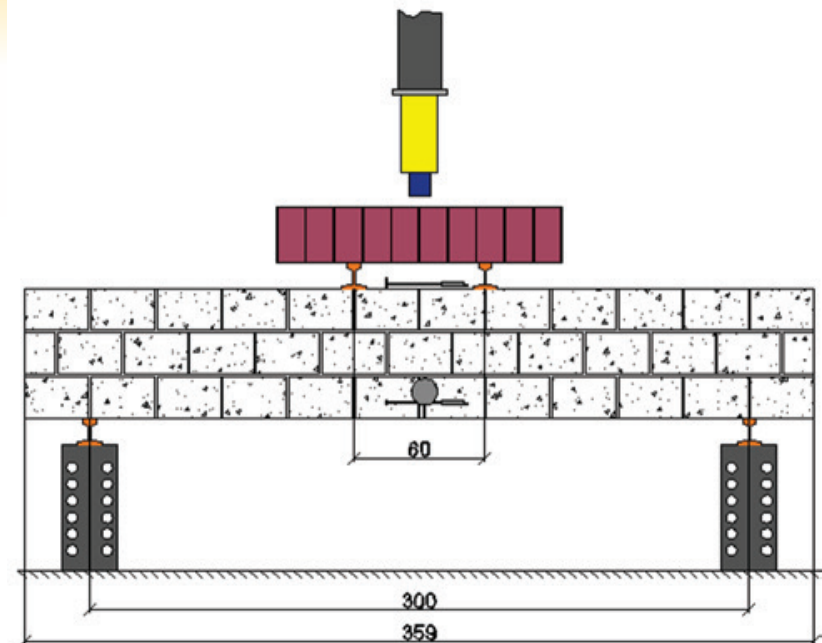

b Test set-up for the 3-course beams dimensions in centimeter

Figure 11

Four-point pure bending testing of the 2 and 3-course beams

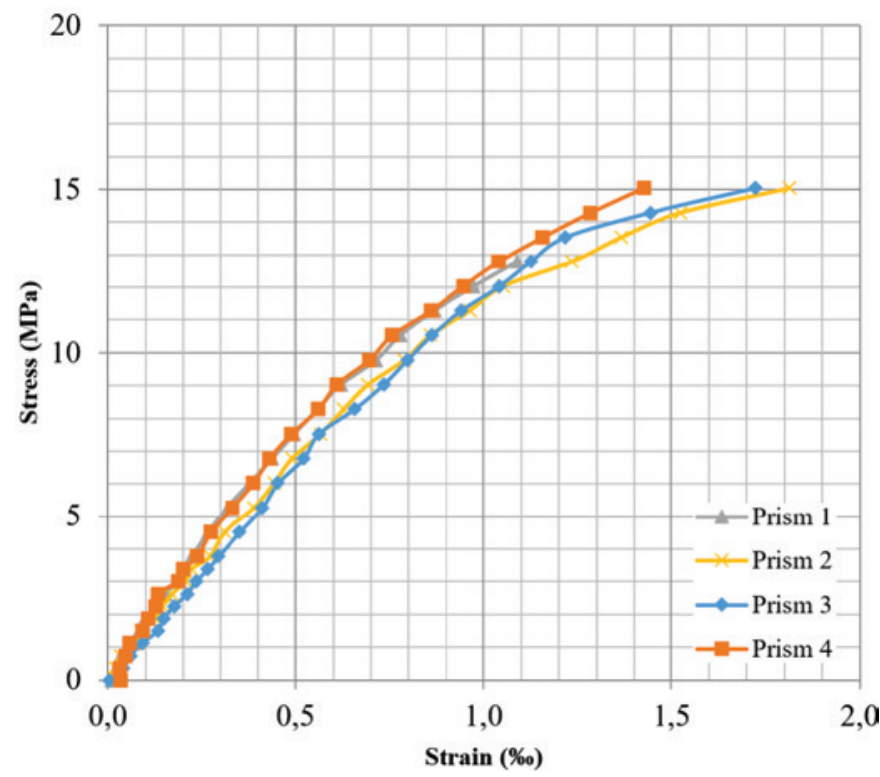

Figure 12

Stress vs Strain curve of the lateral prism

\subsection{Results of the lateral prism and regular prism testing}

The lateral prism and regular prism testing results, as well as the relationship between these two resistances, are shown in Table 6 .

Using the loading data obtained by the load cell and the deformation data through the LVDT's, it was possible to plot the stress vs strain curve for the lateral prism specimens, as shown in Figure 12. In these curves it is noted that the curves for the 3 specimens (Prisma 2, Prisma 3 and Prisma 4) reach the stress of $15 \mathrm{MPa}$, which does not correspond with the maximum strength of each prism shown in Table 6. This occur because the LVDTs lost their reading after this loading level. Thus, the curves include values only values up to $15 \mathrm{MPa}$. On the average, the compressive strength of the lateral prims was $15.40 \mathrm{MPa}$, and that of the regular prims of $20.37 \mathrm{MPa}$, with the mean ratio between these two resistances equal to 0.75 . To calculate the ultimate theoretical bending moment, the average compressive strength of the lateral prims was used. The ultimate masonry shortening strain of each lateral prism was also measured, and from that the average ultimate masonry strain into axial compression was calculated equal to $1.65 \%$.

The mode of rupture of the prims was the result of the lateral deformation of the stressed grout pressing the lateral walls of

Table 6

Results from the lateral prism and regular prism testing

\begin{tabular}{ccccc}
\hline \multicolumn{2}{c}{ Lateral prism } & \multicolumn{2}{c}{ Regular prism } & \\
\cline { 1 - 3 } Test specimen & $\begin{array}{c}\text { Compressive strength } \\
\text { (MPa) }\end{array}$ & Test specimen & $\begin{array}{c}\text { Compressive strength } \\
\text { (MPa) }\end{array}$ & Ratio' \\
\hline 1 & 13.31 & 1 & 18.53 & 0.72 \\
2 & 14.87 & 2 & 19.16 & 0.78 \\
3 & 15.66 & 3 & 21.03 & 0.75 \\
4 & 17.73 & 4 & 22.75 & 0.78 \\
Average & 15.40 & 2 & 20.37 & 0.75 \\
\hline
\end{tabular}

'Ratio: relation between the compressive strength of the lateral prism to the regular prism. 


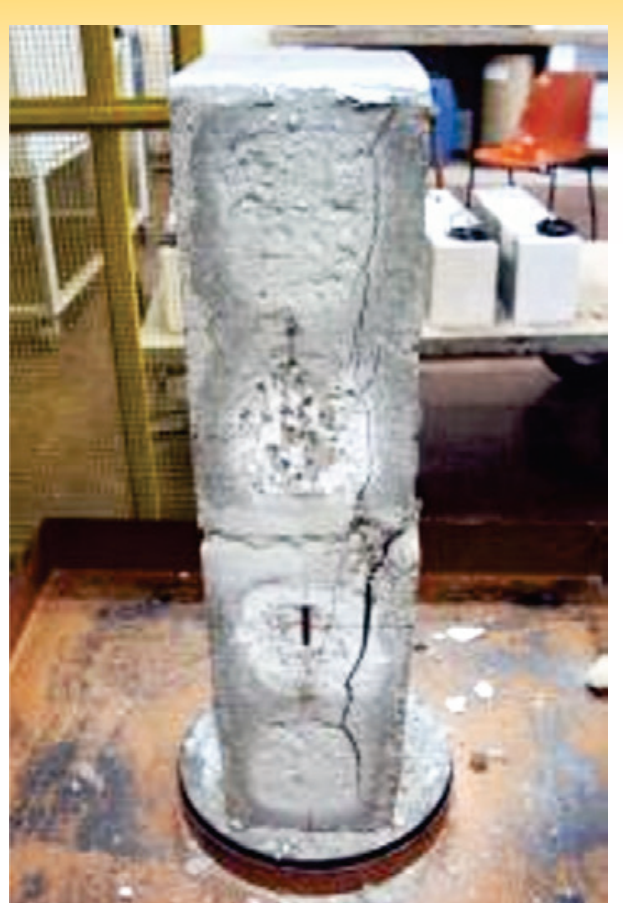

Figure 13

Lateral prism after testing

the block, causing the rupture of the assemble, as shown in Figure 13.

\subsection{Results of the reinforced structural masonry beams testing}

The bending moment vs beam displacement at mid-spam curves obtained from the four-point testing on the 2 and 3-course beams are illustrated in Figures 14 (a) and 14 (b).

The increase in the number of the beams courses was the main factor for increasing the beam stiffness. Looking at the plot, the change in the curve slope at the beginning of the test indicates the moment that each beam started to crack. Table 7 show the average cracking moment for each set of beams teste. Those values where estimated from the data readings and visual observation. From the instrumentation used in the beams, it is also able to plot

\section{Table 7}

Average values of the cracking moment for each beam type

\begin{tabular}{cc}
\hline Beam specimen & $\begin{array}{c}\text { Cracking } \\
\text { moment - average values } \\
\text { (kN.cm) }\end{array}$ \\
\hline V2F1 & 465 \\
V2F2 & 720 \\
\hline V2F3 & \\
V2F4 & 1,195 \\
\hline V2F5 & \\
V2F6 & 2,070 \\
V2F7 & \\
V3F1 & 2,670 \\
V3F2 & \\
\hline V3F3 & \\
V3F4 & \\
V3F5 &
\end{tabular}

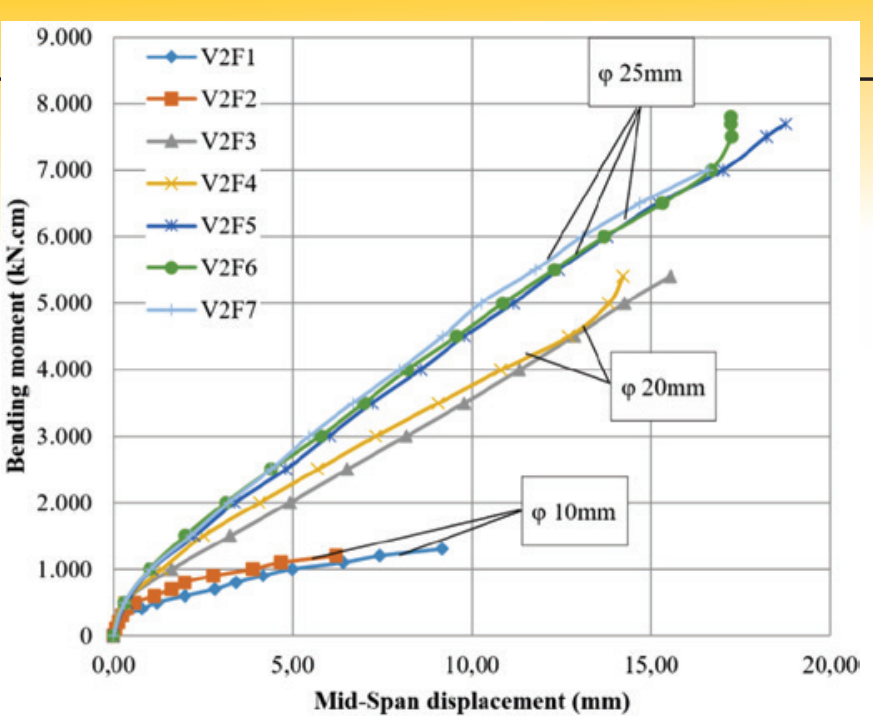

a 2-course beam

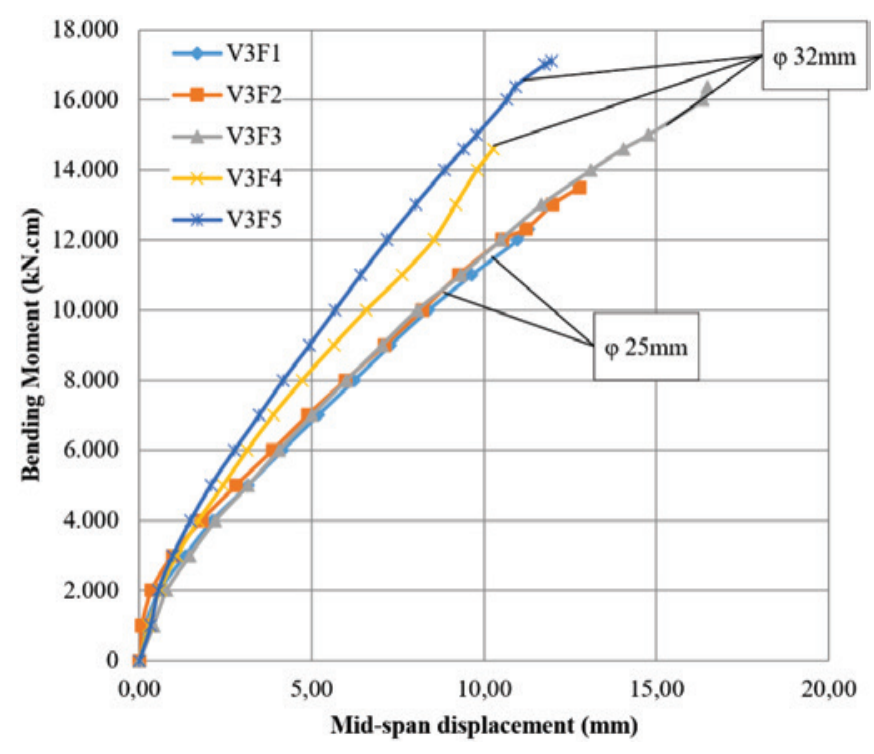

b 3-course beam

\section{Figure 14}

Bending moment vs mid-span displacement curve for the 2 and 3-course beams

the bending moment vs masonry strain curve and the bending moment vs steel strain curve, shown at Figures 15 and 16. It is observed that in Figure 16 there is no V3F3 beam curve because, for this specimen, the longitudinal reinforcement has not been instrumented with the strain gage.

The ultimate masonry deformation strain in the pure flexure region ranged from $1.55 \%$ o to $5.90 \%$ and, on average, this ultimate strain was $3.35 \%$. The strain deformation of the steel at failure ranged from $1.74 \%$ to $3.98 \%$, showing that in none of the cases the steel reached 10\%, which is the limit allowed by NBR 15961-1 (2011) [4]. From masonry ultimate results in the axial compression testing (prism test) and in the pure bending testing (beam test), and from the strain of the steel at the ultimate load in the beam tests, it was adopted the values of $1.5 \%, 3 \%$ and $5 \%$ for the each of those strain values, respectively, to determine the neutral axis position of reinforced structural masonry beams ultimate load, as shown in Figure 17.

To calculate the ultimate bending moment of the reinforced structural masonry beams, Eq. (2) was used, obtained 


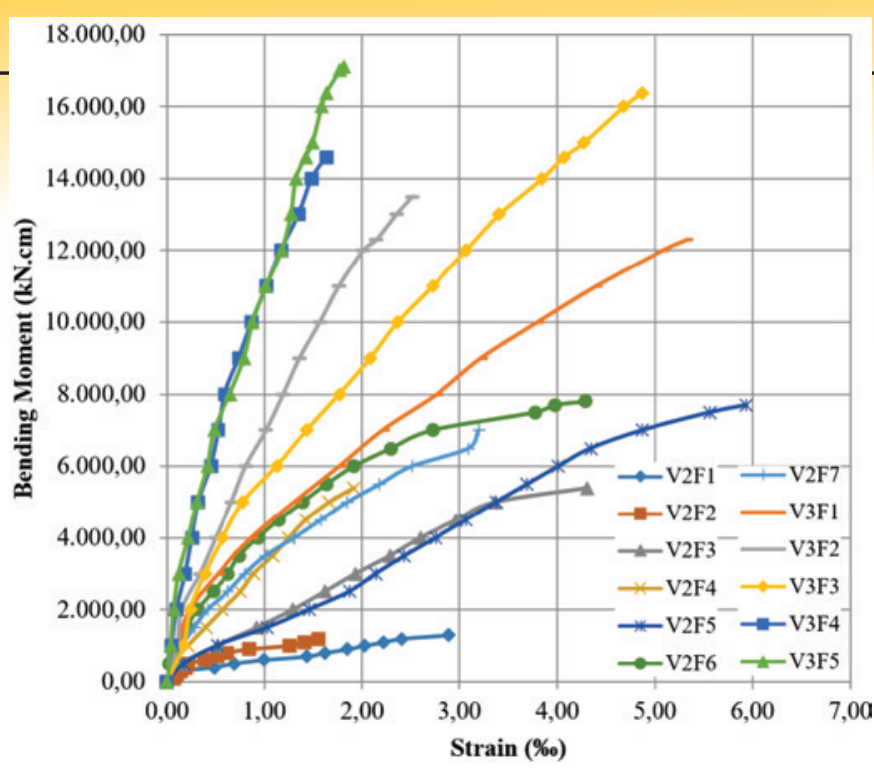

through the balance of forces for the model illustrated in Figure 18.

$M_{u, t e o}=A_{s} \cdot f_{y k} \cdot d \cdot\left(1-\frac{0,5 \cdot A_{s} \cdot f_{y k}}{b \cdot d \cdot f_{p m}}\right)$

Thus, with the data in Table 1, using the steel characteristic yield strength $\mathrm{f}_{\mathrm{yk}}=500 \mathrm{MPa}$ and masonry average compression strength $\mathrm{f}_{\mathrm{pm}}=15.40 \mathrm{MPa}$, it was possible to perform the comparison between the ultimate experimental and theoretical bending moments, illustrated in Table 8. No reduction in steel yield strength, as specified by the NBR 15961-1 (2011) [4], was considered because it was not verified the occurrence of the any separation at the grout/block interface or at the reinforcement bar /grout interfaces after the beam's failure. From Table 8, one can note that the results of the predicted theoretical values are close to those

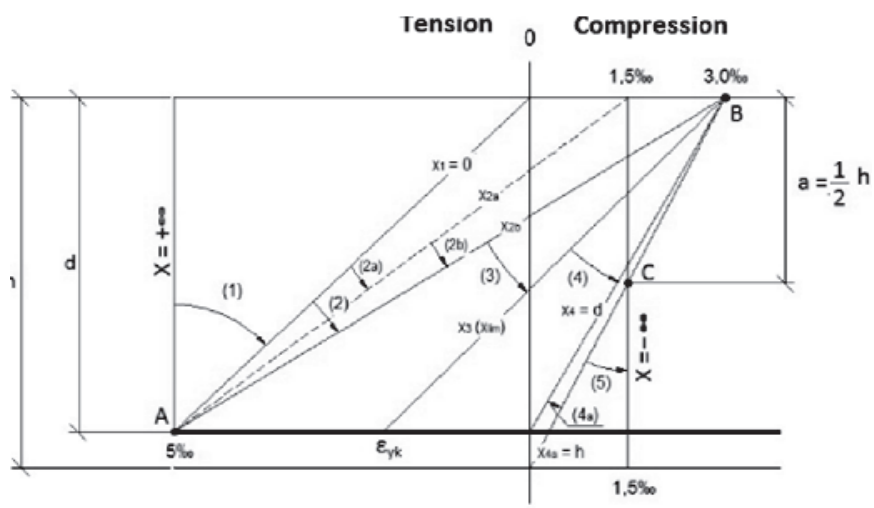

$$
\begin{aligned}
& x_{2 a}=0,213 \cdot d \\
& x_{2 b}=0,375 \cdot d \\
& x_{3}=\frac{0,003}{\varepsilon_{y k}+0,003}
\end{aligned}
$$

Figure 17

Proposed deformation domains for reinforced structural masonry beams

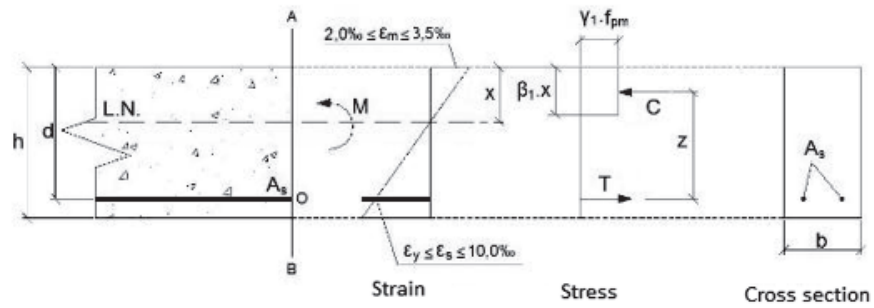

Figure 18

Flexural section design model

\section{Table 8}

Comparison between the ultimate experimental and theoretical bending moments

\begin{tabular}{cccc}
\hline Specimen & $\begin{array}{c}\mathbf{M}_{\mathbf{u}, \text { Exp }}{ }^{1} \\
(\mathbf{k N . c m})\end{array}$ & $\begin{array}{c}\mathbf{M}_{\mathrm{u}, \text { Teo }}{ }^{2} \\
(\mathbf{k N . c m})\end{array}$ & $\begin{array}{c}\text { Ratio }^{3} \\
(\%)\end{array}$ \\
\hline V2F1 & $1,316.40$ & $1,130.87$ & 85.91 \\
V2F2 & $1,186.04$ & $1,202.87$ & 101.42 \\
V2F3 & $5,360.44$ & $4,306.84$ & 80.34 \\
V2F4 & $5,404.80$ & $4,228.09$ & 78.23 \\
V2F5 & $7,727.40$ & $6,249.61$ & 80.88 \\
V2F6 & $7,830.60$ & $6,349.61$ & 81.09 \\
V2F7 & $7,202.40$ & $6,299.61$ & 87.47 \\
V3F1 & $12,333.57$ & $11,799.61$ & 95.67 \\
V3F2 & $13,576.06$ & $11,649.61$ & 85.81 \\
V3F3 & $16,391.97$ & $16,927.01$ & 103.26 \\
V3F4 & $14,617.20$ & $16,927.01$ & 115.80 \\
V3F5 & $17,184.60$ & $17,407.01$ & 101.29 \\
\hline
\end{tabular}




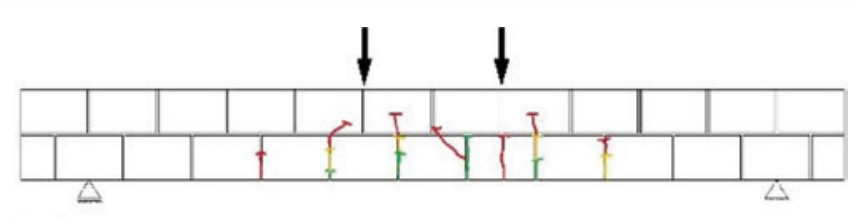

$-25 \%(0-329.10 \mathrm{kN} \mathrm{cm})$

$25-50 \%(329,10-658.20 \mathrm{kN} . \mathrm{cm})$

- $50-75 \%(658,20-987,30 \mathrm{kN}$

75 - $100 \%(987,30-1.316,40 \mathrm{kN} . \mathrm{cm})$

a Beams V2F1 and V2F2

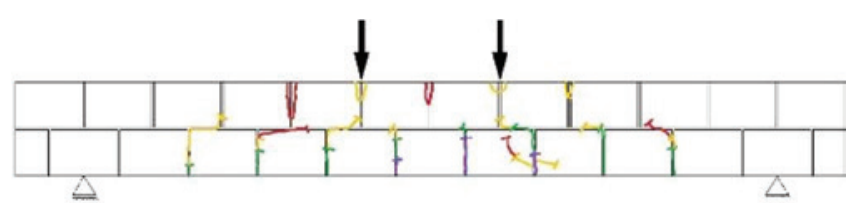

$0.25 \%(0-1.957,65 \mathrm{kN} . \mathrm{cm})$

$25-50 \%(1.957,65-3.915,30 \mathrm{kN} . \mathrm{cm})$

$50-75 \%(3.915,30-5.872 .95 \mathrm{kN} . \mathrm{cm})$

75 - $100 \%(5.872,95-7.830,60 \mathrm{kN} . \mathrm{cm})$

C V2F5, V2F6, and V2F7

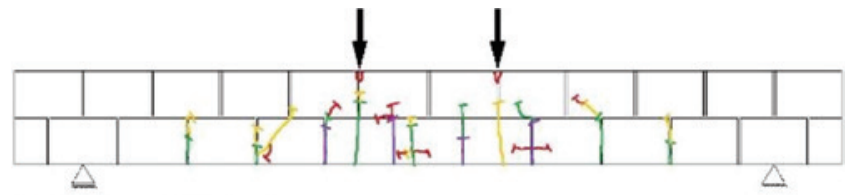

$0-25 \%(0-1.351 .20 \mathrm{kN} \mathrm{cm})$

$25.50 \%(1.351,20 \cdot 2.702,40 \mathrm{kN} . \mathrm{cm})$

$50 \cdot 75 \%(2.702,40-4.053,60 \mathrm{kN} . \mathrm{cm})$

$75-100 \%(4.053,60-5.404,80 \mathrm{kN} . \mathrm{cm})$

b Beams V2F3 and V2F4

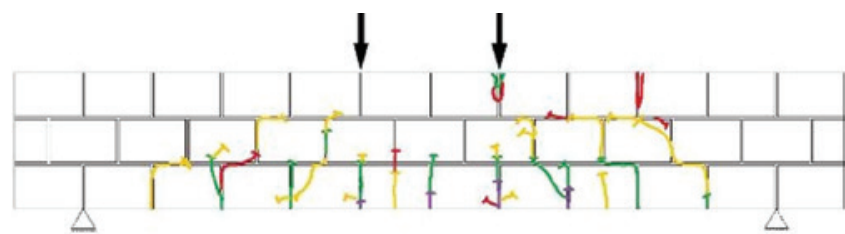

$0.25 \%(0-3.394,02 \mathrm{kN} . \mathrm{cm}$

$25-50 \%(3.394,02 \cdot 6.788,03 \mathrm{kN} . \mathrm{cm})$

$50-75 \%(6.788,03 \cdot 10.182,04 \mathrm{kN} . \mathrm{cm})$

$75-100 \%(10.182 .04-13576,06 \mathrm{kN}$ cm $)$

d V3F1 and V3F2

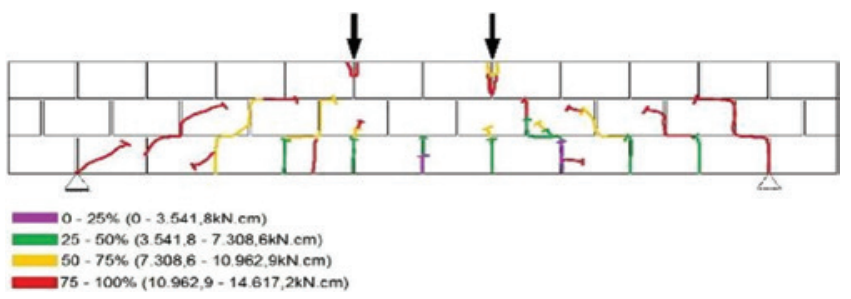

e V3F3, V3F4, and V3F5

\section{Figure 19}

Reinforced structural masonry beams cracking history

obtained in the tests. The values theoretically calculated results between $22 \%$ lower (conservative) and $3 \%$ higher (practically equal) to those of the test results. Therefore, there is no reason to reduce the yield strength in steel in concrete block beams and is worth the same theory of reinforced concrete beams.

Regarding the cracking pattern of the beams, it was observed, in most cases, cracks at the vertical and horizontal joints. With increasing loading, the cracks propagated in the direction of the load points. In the 3-course beams (V3F4, V3F5 and V3F6), that had the highest reinforcement rate, cracking occurred closer to the supports, indicating some influence of the shear stresses to the cracking, and probably those beams behavior is closer to the truss model than to the adopted bending model. The cracking history of each beam group is illustrated in Figures 19 (a) up to 19 (e).

\section{Conclusions}

Based on the results obtained, it was concluded that:

1. From the axial compression testing, on average, the compressive strength of the masonry parallel to the horizontal joints corresponds to $75 \%$ of the compressive strength of the masonry in the other direction (perpendicular to the horizontal joints);

2. With the insertion of more block course, there was an increase in stiffness of the structural masonry beams;

3. During the flexural testing, the cracks emerged predominantly in the vertical and horizontal joints;

4. The design-model used for the dimensioning of the reinforced structural masonry beams section is satisfactory, providing values close to the experimental results;

5. There is no reason to reduce the steel yield strength in the flexural design of reinforced concrete block masonry beams and the same theory for reinforced concrete beams can be adopted; and

6. The ultimate masonry axial compression strain was $50 \%$ lower than ultimate masonry flexural compression strain.

\section{Acknowledgement}

Authors acknowledge the companies COPEL, ENGENHARIA, 
INDUSTRIA E COMÉRCIO LTDA. And TECNOBENS, both from Araçatuba - SP, for the donation of concrete blocks and images. The Company Arcelormittal Brazil from Piracicaba - SP for the donation of steel reinforcement. And the City of llha Solteira - SP, for the donation of the aggregates.

\section{References}

[1] PARSEKIAN, G. A.; HAMID, A. A.; DRYSDALE, R. G. "Comportamento e dimensionamento de alvenaria estrutural", São Carlos: Edufscar, 2012. 625 p.

[2] AUSTRALIAN STANDARD - AS. AS 3700-2001, "Masonry Structures," Standards Australia, Sydney, NSW, Australia, 2001, 191 pp.

[3] BRITISH STANDARDS INSTITUTIONS - BSI. BS 5628:2, "Code of practice for the use of masonry - Part 2: Structural use of reinforced and prestressed masonry" - Londres, 2005. $66 \mathrm{p}$

[4] ASSOCIAÇÃO BRASILEIRA DE NORMAS TÉCNICAS ABNT. NBR 15961-1, "Alvenaria estrutural - blocos de concreto: Projeto", Rio de Janeiro, 2011. 33 p.

[5] CANADIAN STANDARDS ASSOCIATION - CSA. CSA S304.1-04, 2004a, "Design of Masonry Structures," Canadian Standards Association (CSA), Mississauga, ON, Canada, $148 \mathrm{pp}$.

[6] F. KHALAF, F.; GLANVILLE, J.; SHAHAWI, M. EL, "A Study of Flexure in Reinforced Masonry Beams," Concrete International Journal, Vol. 5, No. 7, July 1983, 46-55.

[7] SUTER, G. T.; FENTON, G. A, "Flexural Capacity of Reinforced Masonry Members", ACl Journal, Proceedings V. 83, No. 1, Jan.-Feb. 1986, pp. 127-136.

[8] RING, T, DAS, S. and STUBBS, D, "Compressive Strength of Concrete Masonry Beams", ACl Structural Journal, V. 109, No. 3, May-June 2012, pp.369-376.

[9] ASTM C1314-12 (2012), "Standard Test Method for Compressive Strength of Masonry Prisms", ASTM International, West Conshohocken, PA, 10 pp.

[10] WONG, H. E.; DRYSDALE, R. G, "Compression Characteristics of Concrete Block Masonry Prisms", Masonry: Research, Application and Problems, ASTM STP 871, J.C. Grogan and J.T. Conway, Eds., American Society for Testing and Materials, Philadelphia, 1985, pp. 167-177.

[11] FEREIG, S. M, "Shear Strength of Reinforced Concrete Masonry Beams with Web Reinforcement", ACI Structural Journal, V. 91, No.4, July-Aug. 1994, pp. 415-422.

[12] LANDINI, F. S, "Comportamento à flexão e ao esforço cortante de vigas em alvenaria estrutural". Dissertação (Mestrado) - Universidade Estadual de Campinas, Faculdade de Engenharia Civil, Campinas, 2001. 119 p.

[13] RAMOS, A. P, "Análise experimental do comportamento de vigas mistas de concreto e alvenaria estrutural sujeitas à flexão simples". 2012. 78 f. Dissertação (Mestrado em Engenharia Civil) - Faculdade de Engenharia, Universidade Estadual Paulista, Ilha Solteira, 2012.

[14] ASSOCIAÇÃO BRASILEIRA DE NORMAS TÉCNICAS - ABNT. NBR 6136, "Blocos vazados de concreto simples para alvenaria - Requisitos”, Rio de Janeiro, 2014. 10 p. 